\title{
Mafalala: Memory of a Sociocultural Landscape
}

\author{
FRANCISCO NOA
}

Universidade Lúrio

\begin{abstract}
This article is a reflection on the cultural and political importance of the Maputo neighborhood of Mafalala on the Mozambican national imaginary. It draws on the author's childhood experiences of living in the district, and reads Mafalala as a cosmopolitan melting pot ahead of its time
\end{abstract}

Keywords: Mafalala; Maputo; Memory; Cosmopolitanism; Mozambican imaginary

Is it possible to achieve an inner harmony between images distant in time, scattered in form, and an unsettling, very often unsustainable reality that the present places before us? ${ }^{1}$ This is an age-old issue, one that fluctuates between anguish and pleasure as the past left behind emerges vividly and powerfully to challenge us.

Literature, either consciously or unconsciously, often pursues that harmony. The past, as if charmed by a magic spell, is not always easy to interpret and only exists through memory, often appearing as a more or less ordered place fixed in time. The present, in contrast, representing our coming into being, and what is happening in the moment, is elusive, and for this very reason, a space of ephemeral accomplishments, when not suffering or even bewilderment.

\footnotetext{
${ }^{1}$ This article results from the project "De S. Paulo de Luanda a Luuanda, de Lourenço Marques a Maputo: capitais coloniais em tempos pós-coloniais" (PTDC/CLELLI/122229/2010 - FCOMP-01- 0124-FEDER- 019830), which was financed by Fundos FEDER through the Programa Operacional Factores de Competitividade and by the Fundação para a Ciência e a Tecnologia.
} 
I spent practically all my childhood in Mafalala, up to when I lost my father at the age of nine, and all the innocence of a lifestyle that would never be repeated also went up in smoke. Mafalala was the center of the world, at least for those of us who lived there, and everything that existed focused on this center around which everything else gravitated. Everything gravitated around us, whether it was the cement city then called Lourenço Marques, or the tarmac frontier, at Avenida Craveiro Lopes, which either distanced us or made us closer to Malhangalene, an urban neighborhood of comfortably well-off settlers, or the Munhuana neighborhood, through Avenida Caldas Xavier, or the well-known Indígena, Chamanculo and Xipamanine neighborhoods, close to Avenida de Angola.

In a rather perverse manner, in an exemplary perception of the relativity of things, everything around us seemed to happen and make sense according to our specific existential circle. In this regard, I cannot but share the delightfully vibrant excerpt of a late colonial novel, Ku Femba, written by João Salva-Rey:

Mafalala centro do mundo!

Começara por ser um bairro segregado, meia dúzia de palhotas de caniço amontoado na periferia da cidade dos brancos ou xilunguine, ali se juntando em comunidade, principalmente os oriundos do norte, só macuas, de cofió vermelho enfiado no cocuruto, e longos guarda-pós brancos por cima das calças, óptimos criados de servir, para isso desceram ao sul, praticantes da mesma língua e da mesma religião de Maomet.

Vieram e multiplicaram-se.

E Mafalala cresceu, dia a dia, de palhota em palhota.

Depois, chegou a novidade das construções de madeira e zinco, uma das primeiras a erguer-se, a do bar-dancing 'Comoreano,' iniciativa de um emigrante ousado das ilhas vizinhas das Comores, ali chegado ninguém sabe porquê e, como bom maometano que se prezava, na Mafalala radicado....

Nessa época, distante de quarenta anos, já muitos brancos do xilunguine mandavam às urtigas o preconceito segregatório do pudor saxónico, e uns por facécia, outros simplesmente desinibidos, dançavam com 
mulheres e beberricavam com homens africanos, embora no proscrito e quase incógnito ‘Comoreano' dos recônditos da Mafalala. (277)

A truly paradoxical neighborhood, Mafalala emerged olympically between other borders, that is, two brothels, the Lagoas to the east and Mathlothlomana to the west. "História das Lagoas" is one of the most famous poems by José Craveirinha, and it deals with the living conditions of many African, black, and mulatto women on the periphery of Lourenço Marques:

Vem não vem marinheiro

Coitado filho da Leta

Coitada mãe de sua mãe

Coitada janela acesa na barraca das Lagoas

Coitados nós todos filhos

De coitada Leta Conceição! (75)

The paradox resides in the simple fact that the dignity sandwiched in the wood and zinc houses inhabited by humble families predominantly of African origin lived on a daily basis, side-by-side and naturally, with one of the most degrading and outrageous infamies generated by colonialism: prostitution.

Meanwhile, to the north, currently along Avenida Joaquim Chissano, was one of the mandatory and prohibited places of pilgrimage of our irreverent and carefree childhood, almost always punished by the avenging stick of righteousness wielded by our parents: I am referring to the bocaria. This was nothing less than the largest rubbish dump of the city, where the discarded items of the occupants of the colonial city fired up our imagination. Numerous toys were retrieved from here, reinvented and recycled by our insurmountable creativity of suburban engineering.

Our engineering could not prevent the enormous damage caused by the rains laying bare all the vulnerability and precariousness in which we lived. Even so, the unbridled enthusiasm of our lives remained. A place of cyclical floods, in this aspect in particular, Mafalala inspired, among others, musicians such as Fani Mpfumo and António William, and writers such as Aldino Muianga. Indeed, one of the best-known books by Muianga is Xitala Mati, which in Ronga means "place of the floods." 
In the midst of the adversities with which life confronted us, although in illo tempore we did not see it as such or in the dramatic dimension that it was perceived by the more elderly among us, respect for others and our traditions was held by almost all families as a supreme and non-negotiable value. This high sense of community existence was associated with a deep-seated and intense sense of our ability to overcome obstacles, always with the tireless encouragement of our parents, through their words and by their example. This may explain, to a large extent, why some of the most prominent figures of the forthcoming nation came from there: intellectuals, politicians, nationalists, athletes, musicians, and poets.

A veritable microcosm of Mozambican society, Mafalala is certainly one of the largest flagships of the polychromatic multiculturalism that characterizes this latitudinal borderline country also significantly bathed by the Indian Ocean. With each one ensconced in his own little world, opening up according to daily needs, Mafalala was home to blacks, mulattos, Indians, Chinese, and some white people, with these last three forming well-defined groups, as they were mostly traders, or cantineiros, as they were called at that time.

This atmosphere is vividly captured in the "Poema da Infância Distante" by Noémia de Sousa, where the presence of the sea and the human diversity it brought about are celebrated in an epic manner:

Quando eu nasci na grande casa à beira-mar era meio-dia e o sol brilhava sobre o Índico. Gaivotas pairavam, brancas, doidas de azul.

Os barcos dos pescadores indianos não tinham regressado ainda.

Arrastando as redes pejadas....

-Figuras inesquecíveis da minha infância arrapazada, solta e feliz:

meninos negros e mulatos, brancos e indianos, filhos da mainata, do padeiro, do negro do bote, do carpinteiro...

Today, looking at the debasing spectacle of rabid intolerance throughout our world, or otherwise, at hardened, wrathful and mistrusting faces, and towards the re-erected walls and fields of barbed wire with which Europe, civilized and 
cultured, receives those fleeing from their national and local poverty, I can now see that Mafalala, as a microcosm of an entire nation, was certainly a place ahead of its time.

An effect of colonization and internal migrations, more than any other Mozambican neighborhood, Mafalala established itself as a notable laboratory trial of multi-ethnic, multicultural, and multiracial cohabitation. This, it must be understood, took place in an unplanned and rather contradictory manner, which is rather surprising, given the characteristics of Portuguese colonialism in Mozambique, with its profoundly segregationist hierarchies.

Before we actually knew that we were part of a constellation that was boldly classified as specifically Mozambican, in our daily life and through almost spontaneous learning about "difference," we became aware that, among others, we were Rongas, Manhambanes, Machanganas, Chopes, Matsuas, or simply Xingondos. People were called by their place of origin, either from the center of the country (Senas, Ndaus, Nyunguès, or Machuabos) or from the north (especially Macuas).

This was how the cultural, performative nation was progressively built, as Homi Bhabha explains it, just as in any other part of the world, this is what cements the political nation or the nation-state into which, in our case, Mozambique was transformed, after political independence in 1975.

One of the most powerful images that strongly lingers with me from those times, and which slides between a fading memory and the sharpness of the figures and movements, was the visibility of culture. On Sundays, in spite of political persecution, a large number of cultural groups paraded, enchanting our burgeoning senses. These were unique and very special occasions in which we came into contact with a significant part of our cultural heritage. Inevitably, this gave rise to strong feelings, despite the cultural and linguistic alienation to which we were submitted, through assimilatory practices that involved schooling, censorship, and induced and coercive abdication.

A simple but illustrative example of this alienation was the remarkable circumstance that, in our home environment and beyond, through the rigid imposition of our parents, we were not allowed to use any language other than Portuguese. So, due to irreverence or some atavistic calling, we ended up learning the indigenous languages and other manifestations deeply rooted in the vast and 
diversified cultural backwaters of Mozambicans in the narrow but also gigantic streets of Mafalala.

This learning took place throughout the day during the endless pranks and games played by the neighborhood children. Or during the colder evenings when we gathered together, around fireplaces improvised from tires, to share fragments of popular jokes or stories that many of us had heard from our families and close friends who generously and stubbornly ignored the linguistic prohibition imposed by the colonial forces.

Another important opportunity for cultural education occurred on those faraway and unforgettable Sunday afternoons when cheerful and audacious traditional groups paraded and exhibited rhythmic performances and dances such as xingombela, xiparatwana, xigubo, makwaela, and timbila. Or else, on the occasion of the celebration of some ritual which was the case, for example, of the circumcision ceremony among the Macua community. Here, our playmates would emerge in the midst of drums and festive singing, completely unrecognizable, transfigured by their solemn poses and serious appearance, wearing clothes that we usually saw on adults, such as a suit and tie.

There were the Macuas from the Ilha de Moçambique who used this ceremony as a way to preserve a cultural legacy that was absolutely disconcerting to our meridional eyes. In this rite of passage to adult life, songs and dances, especially tufo, kept our eyes wide open in an amazement that would remain with us for the rest of our lives.

Nowadays, in the light of history and what is happening all over the world, in addition to what is drawn up as the major challenges of our societies, unjustly considered peripheral, Mafalala imposes itself not necessarily as a place, but rather as an appealing sociocultural reality, an immeasurable private and collective heritage, in view of all the symbolic load that determined, consolidated and involved it.

Rather than a global ethno-landscape, tied to a new order and intensity on a large scale based on the incessant movement of people and groups (Appadurai), or community without a sense of place (Meyrowitz), Mafalala represents a lesson for the future in the way that, quite against the system that engendered it, this community educated us not specifically for globalization, but for cosmopolitanism. Since intercultural competence is currently one of the greatest 
tools for our survival and social, professional, and intellectual affirmation, Mafalala is a school beyond time and space.

When Benedict Anderson refers to the imagined community, it is difficult to deny the role played by memory in the consolidation of this same nation. Invoking Mafalala herein is much more than a gratuitous exercise of this memory, or a nostalgic mimicry of the past, or even the pursuit of a lost motherland or paradise. It is, rather, a search for meaning and direction, through a particular angle, to understand the fundamental grounds of an imagery established as collective heritage before the rapid and massive transfiguration and homogenization of a vital space, shared but fragmented.

This heritage currently acquires, in the light of all these mass migratory movements in Mozambique and in the world in general, a unique meaning due to its institution not as the product of a specific influence, but above all due to being the crossroads of the living experiences of many and varied cultures. This crossroads is at the same time one of the greatest metaphors and one of the highest utopias of a mode of existence in which the awareness of differences did not necessarily imply the annulment of these very differences, but rather led to intercultural dynamics which, while situated in a particular period, still reflect in our time and will reflect in times to come aspects which both demean and elevate the human condition.

\section{Works Cited}

Appadurai, Arjun. Dimensões Culturais da Globalização. Lisbon: Teorema, 2004. Print.

Anderson, Benedict. Imagined Communities: Reflections on the Origin and Spread of Nationalism. London: Verso, 1991. Print.

Bhabha, Homi, ed. Nation and Narration. London: Routledge, 1999. Print.

Craveirinha, José. Karingana ua Karingana. Maputo: Instituto Nacional do Livro e do Disco, 1982. Print.

Meyrowitz, Joshua. No Sense of Place: The Impact of Electronic Media on Social Behavior. Oxford: Oxford UP, 1985. Print.

Muianga, Aldino. Xitala-Mati. 1987. Maputo: Associação dos Escritores Moçambicanos, 2003. Print.

Salva-Rey, João. Ku Femba. Lourenço Marques: Minerva Central, 1974. Print. 
Noa

Sousa, Noémia de. Sangue Negro. Maputo: Associação dos Escritores Moçambicanos, 2001. Print. 